\title{
ВПЛИВ ГЕНОТИПОВИХ ТА ПАРАТИПОВИХ ФАКТОРІВ НА РЕАЛІЗАЦЮЮ МОЛОЧНОЇ ПРОДУКТИВНОСТІ КОРІВ
}

\author{
Войтенко Світлана Леонідівна \\ доктор сільськогосподарських наук, професор \\ Інститут розведення і генетики тварин імені М.B. Зубця НАAН \\ ORCID: 0000-0002-7196-8700 \\ Email: slvoitenko@ukr.net \\ Карунна Тетяна Іванівна \\ кандидат сільськогосподарських наук \\ Полтавська державна аграрна академія \\ ORCID: 0000-0001-9290-8961 \\ Email: popovycht7@gmail.com \\ Шаферівський Богдан Сергійович \\ кандидат сільськогосподарських наук \\ Полтавська державна аграрна академія \\ ORCID: 0000- 0001-5742-5016 \\ Email: bogdanschaferivskyy@rambler.ru \\ Желізняк Іван Миколайович \\ ст. викладач \\ Полтавська державна аграрна академія \\ ORCID: 0000-0002-1515-0541 \\ Email: zhim@ukr.net
}

При формуванні високопродуктивного стада чи одержанні тварин з високим реалізаційним потениіалом необхідно враховувати і поєднувати між собою максимальну кількість чинників довкілля та генотипу. 3 урахуванням чого визначення молочної продуктивності корів української чорно-рябої молочної породи в залежності від природно- кліматичних умов, походження за батьком, лінійної належності, технології виробництва молока, а також року народження відноситься до актуальних проблем сьогодення, вирішення якої слугуватиме підвищенню продовольчої безпеки держави. Нашими дослідженнями встановлено, що переважна більшість корів української чорно-рябої молочної породи в досліджених племінних стадах Полтавщини належать до ліній голштинської породи Валіанта 1650414, Дж. Бесна 5694028588, Елевейшна 1491007, Маршала 2290977, Старбака 352790 і Чіфра 14227381. Природно-екологічні умови регіону, а також технологія виробництва молока в досліджуваних господарствах забезпечили різний прояв реалізаційного потенціалу первісток як різних генеалогічних формувань, так одних і тих само. Найкраще до умов довкілля даного регіону пристосовані дочірні нащадки плідників ліній Елевейшна, Маршала і Чіфра, які за 305 днів першої лактації продукували більше 7000 кг молока не залежно від умов їх утримання. Поєднання генотипових і паратипових чинників забезпечило одержання більше ніж 8000 кг молока за лактацію дочірніми потомками усіх досліджуваних ліній. Доведена роль бугая-плідника у формуванні молочної продуктивності корів дочок навіть за низького рівня годівлі тварин та виробництві молока за традиційної технології. Встановлений достовірний кореляційний зв'язок між надоєм корів першої і другої лактації, що обумовлює добір за однією селекційною ознакою. Виявлена залежність надою корів першої - третьої і вищої лактації від року їх народження, що варто враховувати при створенні високопродуктивного стада.

Ключові слова: корови, бугай, лінія, надій, лактація, рік народження, природно-екологічні умови, технологія виробництва молока.

DOI: https://doi.org/10.32845/bsnau.Ivst.2019.1-2.3

Основою ведення галузі молочного скотарства $є$ підвищення молочної продуктивності корів до генетично запрограмованої межі. 3 цією метою розробляються і впроваджуються нові технології, створюються нові та удосконалюються існуючі породи. Найбільшого розвитку молочне скотарство набуло в країнах, де поряд із біологічними особливостям худоби враховують комплекс генотипових та паратипових чинників, які формують молочну продуктивність. Визнано, що молочна продуктивність відноситься до полігенно обумовлених ознак і залежить від ряду чинників довкілля та генотипу тварини, тому її поліпшення є складною проблемою для фахівців. Дослідженнями науковців встановлено, що молочна продуктивність корів залежить від породи, поєднання порід, племінної цінності бугаїв-плідників, належності до лінії, довкілля, в якому реалізується генетичний потенціал тварин, тобто багатьох гено-та паратипових чинників [1, 8, 9, 14, 15]. Доведена різна реакція одних і тих само генеалогічних формувань на умови зовнішнього середовища. 3 урахуванням чого для формування високопродуктивного стада чи одержання корів з високим реалізаційним потенціалом необхідно враховувати і поєднувати між собою максимальну кількість чинників довкілля та генотипу.

Взаємодія генотипу та середовища при фрормуванні високопродуктивного стада чи створенні нової породи завжди були і залишаються в центрі уваги науковців, оскільки неможливо досягнути бажаних результатів добору тварин за

Вісник Сумського національного аграрного університету Серія «Тваринництво», випуск 1-2 (36-37), 2019 
відповідною селекційною ознакою без урахування умов утримання, годівлі тощо. Особлива роль у формуванні молочної продуктивності корів та прояві її генетичного потенціалу відводиться технології виробництва молока. Нами було доведено, що корови української чорно-рябої молочної породи однакової лінійної належності за різних технологій продукували різну кількість молока за лактацію [4]. Поза технологічні чинники на прояв молочної продуктивності корів впливають природно-кліматичні умови [7]. Визнано, що в конкретних природно-кліматичних умовах вищу продуктивність мала худоба відповідних зональних типів, оскільки при створенні українських молочних порід материнською основою були саме породи, які добре адаптовані і акліматизовані до конкретних умов довкілля [3, 6, 9, 12, 18]. Цей чинник враховувався і при підборі плідників для відтворення маточного стада.

Дослідженнями багатьох науковців встановлений високий ефект селекції від використання кращих племінних бугаїв, а також ліній голштинської породи [10, 16, 17]. Саме тому якість плідника, або його племінна цінність, особливо актуальна наразі, коли в стадах великої рогатої худоби української селекції знаходяться тварини з високою спадковістю за голштинською породою і підвищити їх продуктивність за рахунок відтворного чи вбирного схрещування дедалі складніше. Встановлено, що вплив бугаїв на надій дочок залежно від лактації становив 25,50-28,30, на вміст жиру в молоці - 25,0-27,57\%, що вище, порівняно із впливом матерів корів [13]. Аналогічні результати отримано і іншими авторами. 3 урахуванням чого потрібно постійно моніторингувати питання ефективності використання бугаїв для підвищення продуктивності корів дочок не лише в умовах одного стада, але й регіону, а також визначати та нівелювати чинники, які знижують молочну продуктивність корів.

Матеріали та методи досліджень. Дослідження проведені в племінних стадах Полтавської області, які здійснювали виробництво молока від корів української чорнорябої молочної породи, а саме: ТОВ «Агрофірма ім. Довженка», ТОВ «Лелюхівське», СТОВ «Перемога», ТОВ «Агрофірма «Маяк», СТОВ «Воскобійники», ТОВ «Промінь Приват», ПП «ім. Калашника», агрофірма «Перше Травня», ПСП «Майбородівське», СТОВ «АФ «Оржицька», ТОВ «АФ «Пузиківська» та ДП ДГ «Ім. 9 січня». Для визначення впливу природно-екологічних умов на молочну продуктивність худоби визначали надій корів-первісток найбільш розповсюджених ліній голштинської породи племінних стад Полтавщини. Надій корів визначали за даними племінного обліку за 2018 рік.

Визначення впливу генотипових чинників, безпосе- редньо бугая-плідника і лінії, а також середовищних - року народження корів на їх молочну продуктивність здійснювали в умовах племінного репродуктора «Ім. 9 січня» Полтавської області. Опрацьовані дані молочної продуктивності 483 корів різного походження та року народження за ряд лактацій. Надій корів за 305 днів першої, другої, третьої та вищої лактації визначали за використання електронної інформаційної бази племінного репродуктора у форматі СУМС "Інтесел-Орсек" за 2018 рік.

Статистичне опрацювання експериментальних даних та кореляційний аналіз проводили за методикою Н.А. Плохинского [11] засобами програмного пакету «Statistika 6.0» на ПК [2].

Результати досліджень. В процесі створення української чорно-рябої молочної породи в Полтавському регіоні, в основі якої була симентальська та голландська породи, її генофонд використовували для формування центральносхідного внутрішньопородного типу. Тварини підконтрольних стад даного типу мали високий реалізаційний потенціал молочної продуктивності. Надій корів становив 7-8 тис. кг молока за лактацію $[6,18]$. У подальшому відсутність дієвої системи селекції та контролю у молочному скотарстві України [5] привели до відхилення від догматів функціонування породи, передбаченими програмою її створення, особливо в контексті рекомендованої умовної частки кровності за поліпшувальною породою. Для відтворення поголів'я української чорно-рябої молочної породи в племінних стадах Полтавщини продовжували використовувати плідників голштинської породи, оцінених за якістю потомства здебільшого в Сполучених Штатах Америки та Канаді, а не бугаїв вітчизняної породи. В результаті переважна більшість корів цієї породи на теренах області - це тварини 5-10 покоління від відтворного схрещування, у яких умовна частка кровності за материнською породою не значна. Тому для реалізації їх генетичного потенціалу необхідні сучасні технології, в основі яких - високий рівень годівлі, потоково-цехова система, доїльні зали тощо.

Досліджувані племінні господарства Полтавської області характеризуються різними технологічними підходами до виробництва молока від корів української чорно-рябої молочної породи, в результаті чого первістки дочки плідників одних і тих само ліній мають значну мінливість надою (табл. 1). Нами встановлено, що переважна більшість корів в досліджених племінних стадах Полтавщини належить до ліній Валіанта 1650414, Дж. Бесна 5694028588, Елевейшна 1491007, Маршала 2290977, Старбака 352790 і Чіфа 14227381. При цьому для відтворення найбільше використовувалися бугаї ліній Чіфа, Елевейшна і Старбака.

Таблиця 1

Надій корів української чорно-рябої молочної породи різних генеалогічних формувань в племінних стадах Полтавщини

\begin{tabular}{|l|c|c|c|c|c|}
\hline \multicolumn{1}{|c|}{ Лінія } & К-ть бугаїв & Розряд ПЦ бугаїв & К-ть корів & $\begin{array}{c}\text { Надій за 305 днів першої } \\
\text { лактації, кг }\end{array}$ & $\begin{array}{c}\text { Межі надою першої } \\
\text { лактації, кг }\end{array}$ \\
\hline Валіанта 1650414 & 5 & П4 & 60 & $6929 \pm 417,05$ & $5683-8194$ \\
\hline Дж.Бесна 5694028588 & 2 & $П 4, \Pi 5$ & 172 & 6487 & $6413-6524$ \\
\hline Елевейшна 1491007 & 16 & $П 3, \Pi 4, \Pi 5$ & 477 & $7332 \pm 178,87$ & $5995-8876$ \\
\hline Маршала 2290977 & 9 & $\Pi 4, \Pi 5$ & 569 & $7339 \pm 240,59$ & $6008-8514$ \\
\hline Старбака 352790 & 12 & $П 3, \Pi 4, \Pi 5$ & 436 & $6945 \pm 221,23$ & $5950-8140$ \\
\hline Чіфа 1427381 & 26 & $П 4, \Pi 5, \mathrm{H+}$ & 850 & $7247 \pm 184,93$ & $5110-8470$ \\
\hline
\end{tabular}


Природньо-кліматичні умови Полтавської області, а також технологія виробництва молока в досліджуваних господарствах забезпечили різний прояв реалізаційного потенціалу надою первісток як різних генеалогічних формувань, так одних і тих само. При середньому надою первісток досліджуваних ліній 6229 -7332кг різниця між тваринами найбільш і найменш продуктивних генеалогічних формувань становила 410кг. Якщо взяти до уваги лише середні показники надою корів-первісток, то можна зробити висновок, що найкраще до умов довкілля даного регіону пристосовані дочірні нащадки плідників ліній Елевейшна, Маршала і Чіфа, які за 305 днів першої лактації продукували більше 7000 кг молока. Але мінливість надою тварин конкретної лінії засвідчує значно більшу різницю, яку складно обґрунтувати лише природно-екологічними умовами Полтавщини чи належністю до певної лінії. Ймовірно вирішальну роль відіграє саме поєднання «генотип х середовище», яке сприяє формуванню у тварин відповідної молочної продуктивності. Недооцінювання цього чинника привело до того, що серед дочірніх нащадків досліджуваних ліній знаходяться первістки з надоєм 5-6 тис. кг молока за лактацію, що суперечить не лише можливостям голштинської породи, але й української чорнорябої молочної породи. Одночасно з цим слід визначити, що в області $€$ високопродуктивні племінні стада української чорно-рябої молочної породи, де рівень надою корівпервісток усіх досліджуваних ліній, крім ДЖ. Бесна, переви- щує 8 тис. кг молока за лактацію. Тобто, для тварин створені комфортні умови на які вони відповідають реалізацією можливостей свого генотипу.

У підсумку зроблений висновок, що природнокліматичні умови та належність корів до відповідної лінії чинять не такий суттєвий вплив на молочну продуктивність первісток, як технологія виробництва молока.

Для визначення впливу окремих генотипових та паратипових чинників на формування молочної продуктивності корів в умовах традиційної, не прогресивної технології, ми вивчили продуктивність корів української чорно-рябої молочної породи різного року народження та походження за батьком.

Нашими дослідженнями встановлено, що корови досліджуваних ліній в умовах традиційної технології, в основі якої - стійлово-вигульна система та прив'язне утримання тварин, не високий рівень годівлі, доїння корів у молокопровід, характеризувалися не високими показники надою як за першу, так і подальші лактації. Первістки, дочки бугаїв Гарольда, Тракта, Джута, Даміра і Сталдзіса ліній голштинської породи в таких умовах протягом першої лактації продукували 3044-4021кг молока, другої, відповідно, 3443-4101кг, третьої - 3692-4074 кг (табл. 2). Високий вік у лактаціях корів дочок плідників Тракта і Джута не спряв суттєвому підвищенню їх надоїв, про що свідчать показники вищої лактації.

Надій корів в залежності від походження та лактації

Таблиця 2

\begin{tabular}{|c|c|c|c|c|c|c|}
\hline \multirow{3}{*}{ Кличка бугая } & \multirow{3}{*}{ Лінія } & \multirow{2}{*}{\multicolumn{4}{|c|}{ Надій за 305 днів, кг }} & \multirow{3}{*}{$\begin{array}{c}\text { Вік в } \\
\text { лактаціях }\end{array}$} \\
\hline & & & & & & \\
\hline & & перша лактація & друга лактація & третя лактація & вища лактація & \\
\hline Гарольд 7100574479 & \multirow{2}{*}{ Валіанта 1650414} & $\begin{array}{c}4021 \pm \\
131,1\end{array}$ & $\begin{array}{r}4101 \pm \\
128,5\end{array}$ & 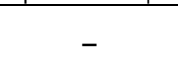 & 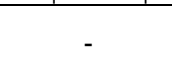 & 2 \\
\hline Тракт 5300000005 & & $\begin{array}{r}3259 \pm \\
150,2 \\
\end{array}$ & $\begin{array}{c}3646 \pm \\
161,8\end{array}$ & $\begin{array}{c}3692 \pm \\
161,8\end{array}$ & $\begin{array}{l}4651 \pm \\
246,2\end{array}$ & 8 \\
\hline Джут 5300000000 & Чiфра 1427381 & $\begin{array}{c}3044 \pm \\
207,3\end{array}$ & $\begin{array}{l}3443 \pm \\
237,2\end{array}$ & $\begin{array}{l}3774 \pm \\
209,2\end{array}$ & $\begin{array}{l}4592 \pm \\
216,9\end{array}$ & 6 \\
\hline Дамир 7100354042 & Белла 1667366 & $\begin{array}{c}3307 \pm \\
91,9\end{array}$ & $\begin{array}{c}3821 \pm \\
108,8\end{array}$ & $\begin{array}{c}3723 \pm \\
156,3\end{array}$ & $\begin{array}{c}4102 \pm \\
86,3\end{array}$ & 3 \\
\hline Сталдзіс 5300000008 & Астронавта 1458744 & $\begin{array}{c}3459 \pm \\
141,4\end{array}$ & $\begin{array}{c}3747 \pm \\
116,1\end{array}$ & $\begin{array}{c}4074 \pm \\
107,5 \\
\end{array}$ & $\begin{array}{c}4596 \pm \\
77,4 \\
\end{array}$ & 5 \\
\hline
\end{tabular}

Проте навіть за таких умов виробництва молока можна відмітити роль плідника у формуванні молочної продуктивності його потомства. Так, бугай Гарольд 7100574479 , який $€$ продовжувачем родоначальника лінії Валіанта 1650414 , забезпечив дочірнім нащадкам вищий надій за ряд лактацій, порівняно з бугаєм Трактом 5300000005, представником цієї ж лінії.

Для визначення можливості добору корів за надоєм першої лактації нами проведений кореляційний аналіз зв'язку показників за ряд лактацій. Доведено, що корови дочки усіх досліджуваних бугаїв, крім Даміра 7100354042 , мають високодостовірну співвідносну мінливість надою першої і другої лактації ( $r=+0,523 \ldots+0,858)$, а Сталдзіса 5300000008 ще й першої - третьої (табл. 3). Тобто, добір корів за показниками надою першої лактації сприятиме підвищенню ознаки наступної лактації.

Таблиця 3

Співвідносна мінливість надою корів різних лактацій

\begin{tabular}{|c|c|c|c|c|}
\hline \multirow{2}{*}{ Кличка бугая } & \multirow{2}{*}{ Лінія } & \multicolumn{3}{|c|}{ Кореляція між лактаціями (r) } \\
\hline & & перша-друга & перша-третя & перша-вища \\
\hline Гарольд 7100574479 & С.В.Д.Валіанта 1650414 & $0,609^{* * *}$ & - & - \\
\hline Тракт 5300000005 & & $0,832^{\star \star \star}$ & 0,268 & 0,604 \\
\hline Джут 5300000000 & П.Ф.А.Чіфра 1427381 & $0,858^{\star \star *}$ & 0,564 & 0,329 \\
\hline Дамир 7100354042 & К.І.Белла 1667366 & 0,045 & 0,335 & 0,279 \\
\hline Сталдзіс 5300000008 & П.Астронавта 1458744 & $0,523^{* * *}$ & $0,399^{* *}$ & $0,664^{* * *}$ \\
\hline
\end{tabular}

Примітка: ${ }^{* *}-P>0,99 ;{ }^{* * *}-P>0,999$ 
Одним із паратипових чинників, на який посилаються дослідники при визначенні його зв'язку з продуктивністю тварин $€$ рік народження корів. При цьому одні дослідники відзначають позитивний зв'язок року народження із форму- ванням молочної продуктивності корів, інші - навпаки заперечують цей факт. За результатами наших дослідженнями встановлено, що рік народження корів мав деякий вплив на їх надій за першу-третю та вищу лактації (табл. 4).

Таблиця 4

Надій корів різного року народження

\begin{tabular}{|l|c|c|}
\hline \multicolumn{1}{|c|}{ Показники } & \multicolumn{2}{|c|}{ Рік народження } \\
\cline { 2 - 3 } & 2010 & 2011 \\
\hline Надій першої лактації, кг & $2882 \pm 97,3$ & $2851 \pm 131,7$ \\
\hline Cv, \% & 14,7 & $3208 \pm 171,2$ \\
\hline Надій другої лактації, кг & $2980 \pm 109,8$ & $3497 \pm 199,2$ \\
\hline Сv, \% & 16,1 & 22,1 \\
\hline Надій третьої лактації, кг & $3292 \pm 189,6$ & $3828 \pm 198,7$ \\
\hline Сv, \% & 25,1 & 20,1 \\
\hline Надій вищої лактації, кг & $4408 \pm 163,9$ & $436 \pm 200,6^{*}$ \\
\hline Сv, \% & 16,2 & 11,0 \\
\hline
\end{tabular}

Примітка: * - $P>0,95$ по відношенню до 2010 року

Так, корови народжені у 2010 році за кількістю молока, одержаного за першу лактацію, переважали на 31 кг народжених у 2011 році, але поступалися одностадницям 2012 року народження на 326кг. Аналіз одержаного молока за другу і третю лактацію від корів 2010-2012 років народження засвідчує достовірну перевагу тварин, народжених у 2012 році, порівняно з 2010 роком та не достовірну, але перевагу народжених у 2011 році, порівняно з 2010 роком. Аналогічна тенденція встановлена й щодо обрахунків даних вищої лактації. Тобто, можна зробити побічний висновок про існування взаємозв'язку між стадом та роком народження тварин, що слід враховувати при його формуванні.

Висновки та перспективи подальших досліджень. Моніторинг молочної продуктивності корів української чорно-рябої молочної породи племінних стад Полтавщини засвідчив, що природно-кліматичні умови та належність корів до відповідної лінії чинять не такий суттєвий вплив на надій первісток, як умови, в яких відбувається виробництво молока. При середньому надою корів досліджуваних ліній в межах 6229кг -7332кг, мінливість обрахованого показнику дочірніх потомків кожної досліджуваної лінії, які продукують молоко в декількох господарствах, значно вища.

Виробництво молока від корів української чорнорябої молочної породи за традиційної технології і не збалансованого рівня годівлі не сприяє прояву їх високого генетичного потенціалу, хоча навіть за таких умов простежується вплив бугая та лінії на продуктивність дочірніх потомків.

Доведено, що корови дочки усіх досліджуваних бугаїв, крім Даміра 7100354042, мають високодостовірну співвідносну мінливість надою першої і другої лактації ( $r=$ $+0,523 \ldots+0,858)$ з урахуванням чого добір корів за показниками надою першої лактації сприятиме підвищенню ознаки за наступну лактацію.

Встановлено, що рік народження корів впливає на їх надій за першу-третю та вищу лактації , що слід враховувати при формуванні високоякісного стада.

\section{Список використаної літератури:}

1. Басовский Н.3. Взаимодействие между генотипом и средой в популяциях молочного скота. Вісник аграрної науки. 1997. № 12. С. 40-43. $2001.56 \mathrm{c}$

2.Боровиков B. STATISTICA. Искусство анализа данных на компьютере: для профессионалов. Санкт-Петербург,

3.Буюклу Г.І. Формування південного типу української чорно-рябої молочної породи в умовах Херсонської області. Вісник Сумського національного аграрного університету. 2002. Вип. 6. С. $72-74$.

4. Войтенко С.Л., Желізняк І.М. Надій корів у залежності від лінійної належності та способу утримання. Розведення і генетика тварин. 2019. Вип. 57. С. 38-44.

5. Зубець М.В., Рубан С.Ю. Система племінної роботи, як засіб виробництва при формуванні порід, що відповідають вимогам ринку. Розведення і генетика тварин. 2010. Вип. 44 . С. 3-10.

6.Ефименко М.Я. Формирование внутрипородной структуры создаваемых пород молочного скота. Розведення і генетика тварин. 2012. Вип.46. С.50-53.

7. Козырь В.С., Коваленко В.П., Геккиев А.Д. Продуктивность голштинов различной эколого-генетической генерации и украинской черно-пестрой молочной породы в условиях степной зоны Украины. Розведення і генетика тварин. 2017. Вип. 53. С. $130-138$

8. Литвиненко Т., Тимченко О. Продуктивність голштинських корів вітчизняної і зарубіжних селекцій. Тваринництво України. 2004. № 7. С. 11 - 12.

9.Любинський О.І. Молочна продуктивність корів різних ліній прикарпатського типу української червоно-рябої молочної породи. Розведення і генетика тварин. 2001. Вип. 34. С. 212-213.

10. Підпала Т.В., Бондар С.О. Успадкування селекційних ознак потомством бугаїв-плідників голштинської породи. Розведення і генетика тварин. 2017. Вип.53. С.173-178

11. Плохинский Н.А. Руководство по биометрии для зоотехников. Москва: Колос, 1969. 256 с.

12. Скляренко Ю.І. Оцінка корів сумського типу української чорно-рябої молочної породи за параметрами екстер'єру та індексами будови тіла. Науково-технічний бюлетень Інституту тваринництва. 2006. № 94. С. 321 -325. 
13. Стадницька О.І. Вплив плідників на формування молочної продуктивності дочок. Матеріали VIII наукової конференції молодих вчених і аспірантів Інституту розведення і генетики тварин. Чубинське, 2010. С. 69.

14. Улимбашев М. Влияние генетических и практических факторов на продуктивное качество коров. Молочное и мясное скотоводство. 2009. № 8. С. 9-10.

15. Х Хельничий Л.М., Вечорка В.В. Генотипові та паратипові чинники впливу на ознаки молочної продуктивності корів української чорно-рябої молочної породи. Вісник Сумського національного аграрного університету. 2014. Вип. 7 (26). С. 87-90.

16. Федорович Є.І., Сірацький Й.3. Вплив батьків на формування молочної продуктивності дочок. Тваринництво України. 2005. № 2. С. 15-17.

17. Филь С.І., Федорович Є.І., Боднар П.В. Динаміка молочної продуктивності корів різних ліній. Розведення $і$ генетика тварин. 2019. Вип.57. С.136-142.

18. Формування внутрішньопородних типів молочної худоби / В.П.Буркат, М.Я.Єфіменко, О.Ф.Хаврук, В.Б.Близніченко. К.: Урожай, 1992. 200 с.

\section{References:}

1. Basovskij, N.Z., 1997. Vzaimodejstvie mezhdu genotipom i sredoj v populyacziyakh molochnogo skota [Interaction between genotype and environment in dairy cattle populations]. Visnyk ahrarnoi nauky, issue,12, pp. 40-43.

2. Borovikov, V., 2001. STATISTICA. Isskustvo analiza dannykh na komp'yutere: dlya professionalov [STATISTICS: Art of computer data analysis: for professionals]. S.-Peterburg.

3. Buiuklu, H.I., 2002. Formuvannia pivdennoho typu ukrainskoi chorno-riaboi molochnoi porody v umovakh Khersonskoi oblasti [ Formation of the southern type of Ukrainian black-and-white dairy breed in the Kherson region]. Visnyk Sumskoho natsionalnoho ahrarnoho universytetu, issue 6, pp. 72-74.

4. Voitenko, S.L., Zhelizniak, I.M., 2019. Nadii koriv u zalezhnosti vid liniinoi nalezhnosti ta sposobu utrymannia [Hope for cows, depending on linear affiliation and method of keeping]. Rozvedennia i henetyka tvaryn, issue 57, pp. 38-44. doi.org.10.31073.abd/57.05

5. Zubets, M. V., Ruban, S. Yu., 2010. Systema pleminnoi roboty, yak zasib vyrobnytstva pry formuvanni porid, shcho vidpovidaiut vymoham rynku [Breeding system as a means of production in the formation of rocks that meet market requirements]. Rozvedennia i henetyka tvaryn, issue 44, pp.3-10.

6. Efimenko M. Ya.,2012. Formirovanie vnutriporodnoj struktury` sozdavaemy`kh porod molochnogo skota [ Formation of the in-breed structure of breeds of dairy cattle]. Rozvedennia i henetyka tvaryn, issue 46, pp.50-53.

7. Kozy'r', V.S., Kovalenko, V.P., Gekkiev, A.D., 2017. Produktivnost' golshtinov razlichnoj e'kologo-geneticheskoj generaczii i ukrainskoj cherno-pestroj molochnoj porody v usloviyakh stepnoj zony' Ukrainy'[ Productivity of Holstein of various ecological and genetic generation and Ukrainian black-motley dairy breed in the steppe zone of Ukraine]. Rozvedennia $i$ henetyka tvaryn, issue 53, pp.130-138.

8. Lytvynenko, T., Tymchenko, O., 2004. Produktyvnist holshtynskykh koriv vitchyznianoi i zarubizhnykh selektsii [Productivity of Holstein cows of domestic and foreign breeding]. Tvarynnytstvo Ukrainy, issue 7, pp.11-12.

9. Liubynskyi, O.I.,2001. Molochna produktyvnist koriv riznykh linii prykarpatskoho typu ukrainskoi chervono-riaboi molochnoi porody. [Dairy performance of cows of different lines of the Carpathian-type Ukrainian red-mottled dairy breed]. ]. Rozvedennia i henetyka tvaryn, issue 34, pp. 212-213.

10. Pidpala, T.V., Bondar, S.O., 2017. Uspadkuvannia selektsiinykh oznak potomstvom buhaiv-plidnykiv holshtynskoi porody [Inheritance of breeding characteristics of offspring of Holstein breed descendants]. Rozvedennia $i$ henetyka tvaryn, issue 53, pp.173-178.

11. Plokhinskij, N.A., 1969. Rukovodstvo po biometrii dlya zootekhnikov. [Biometrics Guide for Livestock Specialists]. Moskva: Kolos.

12. Skliarenko, Yu.I.,2006. Otsinka koriv sumskoho typu ukrainskoi chorno-riaboi molochnoi porody za parametramy eksterieru ta indeksamy budovy tila [Estimation of Sumy cows of Ukrainian black-rumped dairy breed by exterior parameters and body structure indices]. Naukovo-tekhnichnyi biuleten Instytutu tvarynnytstva, issue 94, pp. 321-325.

13. Stadnytska, O.I., 2010. Vplyv plidnykiv na formuvannia molochnoi produktyvnosti dochok [Influence of breeders on formation of dairy productivity of daughters]. Materialy VIII naukovoi konferentsii molodykh vchenykh i aspirantiv Instytutu rozvedennia i henetyky tvaryn. Chubynske. pp.69.

14. Ulimbashev, M.,2009. Vliyanie geneticheskikh i prakticheskikh faktorov na produktivnoe kachestvo korov [The influence of genetic and practical factors on the productive quality of cows]. Molochnoe i myasnoe skotovodstvo, no.8, pp. 9-10.

15. Khmel'nychyi, L.M., Vechorka, V.V., 2014. Henotypovi ta paratypovi chynnyky vplyvu na oznaky molochnoyi produktyvnosti koriv ukrayins'koyi chorno-ryaboyi molochnoyi porody [Genotypic and paratypical factors influencing the traits of milk productivity of Ukrainian Black-andWhite dairy breed]. Visnyk Sumskoho natsionalnoho ahrarnoho universytetu, issue 7 (26), pp.87-90.

16. Fedorovych, Ye.I., Siratskyi, Y.Z., 2014. Vplyv batkiv na formuvannia molochnoi produktyvnosti dochok [The influence of parents on the formation of dairy productivity of daughters]. Tvarynnytstvo Ukrainy, issue 2, pp.15-17.

17. Fyl, S.I., Fedorovych, Ye.I., Bodnar, P.V., 2019. Dynamika molochnoi produktyvnosti koriv riznykh linii [Dynamics of dairy productivity of cows of different lines]. Rozvedennia i henetyka tvaryn, issue 57, pp.136-142. doi.org.10.31073.abd/57.16

18. Burkat, V.P., lefimenko, M.la, Khavruk, O.F., Blyznichenko, V.B., 1992. Formuvannia vnutrishnoporodnykh typiv molochnoi khudoby [Formation of inbred types of dairy cattle]. Kyiv: Urozhai 
Voitenko, S. L.,

Karunna, T. I.,

Shaferivsky, B. S.,

Zheliznyak, I. M.

Influence of genotypic and paratype factors on realization of dairy productivity of cows.

When forming a high-yielding herd or producing animals with high realizational potential, the maximum number of environmental and genotype factors must be considered and combined. Considering that the determination of dairy productivity of cows of Ukrainian black-and-white dairy breed, depending on natural and climatic conditions, parentage, linear affiliation, technology of milk production, as well as the year of birth, refers to pressing problems of today, the solution of which will serve to increase the food security of the state. Our research has established that the vast majority of cows in the Ukrainian black-and-white dairy breed in the studied breeding herds of Poltava region belong to the Holstein breed lines of Valiant 1650414, J. Besna 5694028588, Elevation 1491007, Marshall 2290977, Starbak 135277 and Chif 14227381. Natural and ecological conditions of the region, as well as the technology of milk production in the studied farms provided different manifestation of the realization potential of the cow firstborn of different genealogical formations and of the same. The best suited to the environmental conditions of the region are the children of the offspring of the Elevation, Marshall, and Chif lineages, who produced more than 7,000 kg of milk during the 305 days of the first lactation, regardless of the conditions of their maintenance. The combination of genotypic and paratypical factors resulted in the production of more than $8,000 \mathrm{~kg}$ of lactation milk by the offspring of all the lines studied. The role of the bull-sires in the formation of dairy cow dairy productivity has been proven even at low animal feeding and milk production using traditional technology. A reliable correlation between the milk yield of the first and second lactation cows was established, which determined the selection by one breeding trait. The dependence of milk yield of the first cows - third and higher lactation on the year of their birth is revealed, which should be taken into account when creating a high-yielding herd.

Key words: cow, bull, line, yield, lactation, year of birth, the natural ecological conditions, technology of milk production.

Дата надходження до редакції: 15.08.2019 р. 